\title{
Epidemiological Status of Contagious Bovine Pleuropneumonia in Southern Zone of Tigray Regions, Northern Ethiopia
}

\author{
Teshale Teklue ${ }^{1, *}$, Temesgen Tesfay ${ }^{2}$, Tsigabu Nirayo ${ }^{3}$, Birhanu Hailu ${ }^{4}$, Solomon Wayu ${ }^{2}$, \\ Tesfay Atsbha ${ }^{2}$ \\ ${ }^{1}$ Mekelle Agricultural Research Center, Mekelle, Ethiopia \\ ${ }^{2}$ Alamata Agricultural Research center, Alamata, Ethiopia \\ ${ }^{3}$ Axum Agricultural Research Center, Axum, Ethiopia \\ ${ }^{4}$ Samara University, College of Veterinary Medicine, Department of Veterinary Epidemiology and Preventive Medicine, Samara, Ethiopia \\ Email address: \\ teshale12@gmail.com (T. Teklue), teshalearaya@yahoo.com (T. Teklue)
}

\section{To cite this article:}

Teshale Teklue, Temesgen Tesfay, Tsigabu Nirayo, Birhanu Hailu, Solomon Wayu, Tesfay Atsbha. Epidemiological Status of Contagious Bovine Pleuro Pneumonia in Southern Zone of Tigray Regions, Northern Ethiopia. Animal and Veterinary Sciences.

Vol. 3, No. 1, 2015, pp. 32-36. doi: 10.11648/j.avs.20150301.17

\begin{abstract}
A cross sectional study was conducted from December 2012 to May 2013 to determine the epidemiological status of CBPP in southern zone of Tigray region, Northern Ethiopia. Purposive sampling was used in selection of districts, peasant association and farmers for interview and random sampling was used in selection of animals for serum collection. The questionnaire was provided to 109 informative farmers by face to face interview to know the general animal diseases in the zone and specifically about CBPP. About $26.6 \%$ of the farmers mentioned CBPP as one of the major cattle diseases in the zone. Serum samples from 384 animals were collected to determine the sero-prevalence using complement fixation test. The overall he overall sero-prevalence was $11.9 \%$ ranging from zero $(0 \%)$ to $28 \%$ across different districts. There was no significant $(p<0.05)$ association of sero-prevalence to age and sex groups but was significantly $(p<0.05)$ associated to the agro ecology and implies a great attention at the mid highland and lowland. The present work highlights a need to scheme and implement control measures directing at preventing further spread and lowering the prevalence of the disease in the zone through the use of better and coordinated vaccination program with great emphasis to animal movement routes.
\end{abstract}

Keywords: Epidemiology, Cattle, CBPP, Southern Zone of Tigray

\section{Introduction}

Agriculture is the mainstay of Ethiopia's economy providing $47 \%$ of the Gross Domestic product (GDP), employment to $85 \%$ of the population whereas industry contributes about 5\% and services $10 \%$ (4) Livestock contributes about $25 \%$ to agricultural and $61 \%$ of total export (14). Ethiopia is one of the top ranking countries in Africa and among the first ten in the world in terms of livestock resource. Investment opportunities are potentially attractive for modern commercial livestock breeding, production and processing of meat, milk and eggs (http://www.africa-dobusiness.commention 05.06.2014).

Ethiopia possesses the highest number of livestock in Africa with an estimated 53.99 million cattle, 25.5 million sheep and 24.06 million goats (7). However, the productivity of this livestock sector is lower than the potential level of the African production average. Traditional methods of animal husbandry render the output per unit of domestic breed of livestock to be too low (6). The major biological constraints contributing to low productivity include low genetic potential of the animals, poor nutrition and prevailing diseases $(2,3)$. Among the prevalent diseases Foot and mouth Disease (FMD), Contagious Bovine Pleuropneumonia (CBPP), lumpy skin disease, trypanosomiasis, external parasites and tick borne diseases are main animal health problems in animal health context.

Contagious bovine pleuropneumonia is a highly infectious 
cattle disease, which is caused by Mycoplasma mycoides subspp mycoides SC (small colony, bovine biotype). It is the most economically important disease worldwide (18) and causes high morbidity and mortality losses to cattle (20). Contagious bovine pleuropheumonia is considered as one of the main stumbling blocks to the growth of the livestock industry on the African continent. Yearly losses directly or indirectly due to CBPP in Africa estimated to be is around two billion US dollars (27). Next to the eradication of rinderpest, CBPP is prime concern in African continent (1). It is one of the major threat in Ethiopia hindering and challenging the livestock production system (11, 10 and 12).

Even though there had been many research works in southern zone of Tigray region, there is limited information about the epidemiological status of the CBPP but there are frequent reports of the disease and this study was conducted to assess the epidemiological distribution of the disease in the zone across the different ecology and districts to implement continuous and tighten control and prevention measures both at farming level and outlet as well as inlet markets.

\section{Material and Methods}

\subsection{Study Area Description}

The study was conducted in Southern zone of Tigray Regional State, Northern Ethiopia. The zone is located at $660 \mathrm{~km}$ North of Addis Ababa, capital of Ethiopia and $120 \mathrm{~km}$ South of Mekele, capital city of the Tigray regional state. Geographically it is located at $12^{0} 15^{\prime}$ and $13^{\circ} 41^{\prime}$ north latitude and $38^{\circ} 59^{\prime}$ 'and $39^{\circ} 54^{\prime}$ 'east longitude, constituting an area of $9,446 \mathrm{~km}^{2}$. The zone consists of five administrative districts; the districts are namely Raya Alamata, Alaje, and Endamohoni, Ofla, and Raya azebo under different agro ecological zones. The study area has a total human population of 1,004,558 (12, 4813 from urban and 879,745 from rural) (5). The livestock population consists of 699,559 cattle, 269,098 sheep, 398,503 goats, 950 horses, 160,761 donkeys, 2,154 mule, 13,0303 camel, 845,548 poultry and 52,699 beehives (7). Livestock production is a major component of the livelihood system and provides draught power, food and income.

\subsection{Study Animals}

Herds of cattle managed under the traditional extensive production system were included in this study. Animals were randomly selected and all animals greater than six month in age were selected for serum collection. All animals from which blood samples were collected were apparently healthy and with no history of vaccinations to CBPP.

\subsection{Study Design}

A cross-sectional type of study was conducted from December 2012 to May 2013 in the four districts of southern zone of Tigray region. At the beginning of the study momentary description and discussion about the study was done with the district animal health experts (9) and all data were collected accordingly.

\subsection{Data Collection}

\subsubsection{Questionnaire}

Four districts were selected purposively from the five districts of the zone and from each districts, two peasant associations were included based on number of livestock population and ease of access for transportation (9). The study was done on eight peasant association and a total of 109 farmers were interviewed to collect the community perception. The farmers were selected purposively with the community animal health workers that own livestock species and expected to have experience about animal health. A detailed, organized and structured questionnaire were prepared and administered in person to farmers in an interview to obtain base line information on the existing diseases of ruminants according to the farmers. The questionnaire were pre-tested in the field and adjusted as required, translated into local language in a simple way that the farmers can understand. Main disease of cattle with local name, risk factors, and new diseases observed as well as transmission perceptions were collected as base line to know importance of CBPP in comparison with other cattle diseases in the farming community.

\subsubsection{Sample Size and Serum Collection}

Sample size was determined according to Thrusfield (21) formula and serum from 384 animals were collected randomly from the purposively selected peasant associations for serum collection considering $50 \%$ prevalence since there was no previous study specifically in the study area. Blood sample was collected aseptically from the jugular vein in $10 \mathrm{ml}$ to obtain serum. The serum was kept at $-20^{\circ} \mathrm{C}$ until serological testing (16). Data on sex, age, herd size, animal management, and agro climate of the area were collected along with sampling.

\subsection{Laboratory Analysis}

All sera collected were subjected to Complement Fixation Test (CFT) for the detection of contagious bovine pleura pneumonia antibodies according to OIE (15).

\subsection{Data Analysis}

Data of both community perception and biological collected was stored in the Microsoft Excel spread sheet program and analyzed using SPSS (19) The community perception was described by frequencies and the seroprevalence was estimated by dividing the number of CFT positive animals by the total number of animals tested. Chisquare test was utilized to quantify the relationship between the sero-prevalence with categorical variables (districts), age, sex and agro-ecology. Fisher's exact test was utilized when the outcome variable was below five in number as a substitute for Chi square test in comparing two factors among each other. 


\section{Results}

\subsection{Major Ruminant Diseases in the Study Area According to the Farmers' Perception}

As complementary to serological analysis, the farmers mentioned that the main prevalent large ruminant diseases in the study area were foot and mouth disease (Anashe), contagious bovine pleauro pneumonia (Samba), pasteurellosis (hidhido) and Black leg (Afefta) as presented in table 1. This study agreed to the finding of Yohhanes (22) and Kuastrose (23) who reported CBPP, CCPP, anthrax, black leg and pasteurellosis as the major infectious disease observed in the study area and other parts of the country.

Table 1. Major Ruminant diseases according to community response in Southern Zone of Tigray Region.

\begin{tabular}{|c|c|c|c|c|}
\hline \multicolumn{3}{|l|}{ Major disease of ruminants } & \multicolumn{2}{|c|}{ Respondents } \\
\hline Scientific Name & Local Name & Species & No & $\%$ \\
\hline Foot and Mouth Disease & Anashe & Bovine & 79 & 72.4 \\
\hline Lumpy skin diseases & Dubdubta & Bovine & 7 & 6.4 \\
\hline Anthrax & Tafya & Bovine & 69 & 72.4 \\
\hline Pasteurellosis & Hidhido & Bovine & 41 & 37.6 \\
\hline Contagious bovine pleuro pneumonia & Samba & Bovine & 29 & 26.6 \\
\hline Black leg & Wokie & Bovine & 91 & 83.5 \\
\hline Sheep and goat pox & Enfirir & Caprine & 28 & 26.7 \\
\hline Pastuerellosis & Mieta & Sheep & 42 & 38.5 \\
\hline
\end{tabular}

\subsection{Sero-prevalence of Contagious Bovine Pleuro Pneumonia}

From the total of 384 sera samples examined,thirty six sera were test positive to CFT giving an overall prevalence of
11.9 as indicated in table 2.The highest sero-prevalence was observed in Alamata district (28\%) and lower was $0(0 \%)$ in Ofla and Endamehoni Districts.

Table 2. The Sero-prevalence of CBPP in the districts of Southern Zone of Tigray Region, Northern Ethiopia.

\begin{tabular}{lllll}
\hline District & Number of animal tested & Negative & Positive & District sero-prevalence \\
\hline R/alamata & 105 & 75 & 30 & 28 \\
R/azebo & 106 & 81 & 16 & 15.2 \\
Ofla & 95 & 68 & 0 & 0 \\
E/mehoni & 78 & 63 & 0 & 0 \\
Total & 384 & 338 & 46 & 11.9 \\
\hline
\end{tabular}

As shown in Table 3, the sero-prevalence of CBPP in male animals was $11 \%$ and 12.5 in female animals and the sero-

prevalence between the two sexes were not statistically significant $(\mathrm{p}>0.05)$.

Table 3. Sero-prevalence of CBPPin relation to sex in the four districts of Southern Zone of Tigray region Northern, Ethiopia.

\begin{tabular}{lllll}
\hline District & sex & Number of Animals tested & CFT Positive & Sero-prevalence (\%) \\
\hline Alamata & Male & 30 & 9 & 13.2 \\
& Female & 75 & 21 & 6.8 \\
Raya azebo & Male & 38 & 6 & 8 \\
& Female & 68 & 10 & 33.3 \\
Ofla & Male & 45 & 0 & 0 \\
& Female & 50 & 0 & 0 \\
Endamehoni & Male & 50 & 0 & 0 \\
& Female & 28 & 0 & 0 \\
Total & & 46 & 11.9 \\
\hline
\end{tabular}

Risk factors considered in this study were sex and age of the animals as well as agro-ecology. Sero-prevalence was significantly associated with agro-ecology as indicated in table 4 . 
Table 4. Risk factors associated with animal level Sero-prevalence of CBPP.

\begin{tabular}{|c|c|c|c|c|c|c|}
\hline Factors & & $\mathbf{N}$ & CFT positive & Sero-prevalence & Chi-square & P value \\
\hline \multirow[t]{3}{*}{ Sex of animal } & & & & & $*$ & 0.07 \\
\hline & Female & 216 & 31 & & & \\
\hline & Male & 168 & 15 & & & \\
\hline \multirow[t]{2}{*}{ Age of animals } & $<2$ years & 97 & & & $*$ & 0.28 \\
\hline & $>2$ years & 287 & & & & \\
\hline \multirow[t]{4}{*}{ Agro-ecology } & & & & & 51 & 0.001 \\
\hline & Highland & 173 & & & & \\
\hline & Midhighland & 106 & & & & \\
\hline & Lowland & 105 & & & & \\
\hline
\end{tabular}

$\mathrm{N}=$ number of animals tested

* Fisher's exact test

\section{Discussion}

The result of the serological test $(11.9 \%)$ is complementary to the community perception that CBPP is common disease in the study area, in which $26.6 \%$ of the respondents mentioned CBPP as one of the major cattle disease. The overall sero-prevalence $(11.9 \%)$ in the study area is parallel to other study conducted in different part of Ethiopia under extensive production system; 9.5\% in older animals at different export quarantines of Ethiopia Kassaye and Molla (24), 10\% in Dassenech district of South Omo Zone, South-Western Ethiopia Molla and Delil (25). Other study out of Ethiopia reported is also comparable to this study; 10.65 in Kwara state-Nigeria, by Olabode et al. (26). However, other reports from Ethiopia, $0.4 \%$ by Gezahagn et al., (12) and Erimiyas et al., (10) are lower compared to this study. The variation of these findings might be due to the variation in temporal and spatial distribution of the disease, animal management difference and the sensitivity of the serological tests used. In this study CFT test was used and others used ELISA though CFT is the recommended test by OIE (14). The sero-positivity of CBPP varies significantly among the study districts and this could be due to slight difference in animal movement though with similar production system. The significant $(\mathrm{P}<0.05)$ difference in the sero-prevalence may be due to difference in the districts and agro-ecology. The insignificant $(\mathrm{P}<0.05)$ difference of seroprevalence among sex and age groups may be due to similar exposure of animals to the disease since the disease is contagious that all animal in the herd can be affected and chronic that a single diseased animal can serve as continuous source of infection to the herd. The disease is mainly transmitted from animal to animal in aerosols. This organism also occurs in saliva, urine, fetal membranes and uterine discharges (18). This could play great role in uniformity of infection in all age groups and sexes).

In conclusion, the sero-prevalence of CBPP in the region needs high attention in implementing the disease control and prevention strategies. The sero-prevalence difference was significantly associated to the agroecology and requires a great attention at the mid highland and lowland. Therefore, there is a need to develop scheme and implement control measures directing at preventing further spread and lowering the prevalence of the disease in the zone through the use of better and coordinated vaccination program especially along the animal movement routes.

\section{Acknowledgment}

We would like to express our appreciation to Alamata Agricultural research center in supporting this project both in human power and material. We would like to extend our gratitude to animal health experts of the zone for their unlimited support at the field work.

\section{References}

[1] Amanf W., 2009.Contagious bovine pleuropneumonia (lung sickness) in Africa. Onderstepoort Journal of Veterinary Research, 76:13-17.

[2] Belay, D., K. Yisehak and G.P.J. Janssens, 2012a. Survey of Major Diseases Affecting Dairy Cattle in Jimma Town, Oromia, Ethiopia. Global Veterinaria, 8: 62-66.

[3] Belay, D., K. Yisehak and G.P.J. Janssens, 2012b. Productive and Reproductive Performance of Zebu X Holstein-Friesian Crossbred Dairy Cows in Jimma Town, Oromia, Ethiopia. Global Veterinaria, 8: 67-72.

[4] Bureau of African Affairs, 2006. www.state.gov/r/pa/bgn/2859.htm.

[5] CSA, 2007. Population and Housing Census of Ethiopia, Addis Ababa: Central Statistical Agency

[6] CSA, 2008. Central statistics for livestock population in Ethiopia. Addis Abeba, Ethiopia

[7] CSA, 2013. Central statistics for livestock population in Ethiopia. Addis Abeba, Ethiopia

[8] Coopreck, D.L.1994. The Borenaplaute of southern Ethiopia. Synthesis of pastoral research, development and change, 1986-91. System study International Livestock Center for Africa (ILCA), Addis Ababa, Ethiopia. 
[9] Dohoo, L., Martin,W., and Stryhn,H., 2003. Veterinary Epidemiologic Research. Prince Edward Island, Canada.

[10] Erimiyas Dele, Berihun Afera, Etsay Kebede, Nesibu Awol and Birhanu Hadush, 2014. Sero-prevalence of Trade Hampering Livestock Diseases in Animals Originated from Borana at Export Quarantine Centers in Adama, Central Ethiopia. African Journal of Basic \& Applied Sciences 6 (2): 30-36.

[11] Gedlu Mekonnen, 2004. Serological, Clinical and Participatory Epidemiological Survey of Contagious Bovine Pleuropneumonia in Somali Region, Ethiopia (MSC thesis). Addis Ababa University, Faculty of Veterinary Medicine, Debre-zeit, Ethiopia.

[12] Gezahegn Alemayehu, Samson Leta and Berhanu Hailu, 2014. Low sero-prevalence of Contagious Bovine Pleuropneumonia (CBPP) in bulls originated from Borena Pastoral Area of Southern Ethiopia. Animal and Veterinary Sciences. 2(6): 213217.

[13] ILCA Bulletin, 1980. Small ruminant production .Addis Ababa, Ethiopia, pp2-11.

[14] Livestock Data Innovation in Africa, 2012. www.africalivestockdata.org

[15] OIE Terrestrial Manual, 2008. Contagious bovine Pleuropneumonia.

[16] OIE Terrestrial Manual, 2009. Contagious bovine Pleuropneumonia.

[17] OIE Terrestrial Manual, 2014. Contagious bovine Pleuropneumonia.

[18] Radostits, D.M. Blood, D.C. and Gay, C.C., 2008. Veterinary Medicine. A Textbook of diseases of cattle, sheep, pigs, goats and horses. 8th ed. London. Bailliere Tindal. Pp. 748-785.

[19] SPSS, 2007. Statistical package for social science version 16 by Jim Dalrymple, Macworld Software company, USA.
[20] Tambi, N.E., Maina, W.O. and Ndi, C. 2006. An estimation of the economic impact of contagious bovine pleuropneumonia in Africa. Rev. sci. tech. Off. int. Epiz., 25 (3), 999-012.

[21] Thrusfield M., 2008. Sampling in Veterinary Epidemiology. 3rd ed., Black well Science Ltd, London. 46-65, 228-242 Pp.

[22] Yohannes Tekle, 2007. Major animal health problems of market oriented livestock Development in Alamata Woreda. A thesis submitted to the Faculty of Veterinary Medicine, Addis Ababa University, as a partial fulfillment of the requirements for the attainment of Degree, Doctor of Veterinary Medicine (DVM), Debreziet Ethiopia.

[23] Kuastros Mekonnen, Major animal health problems of market oriented livestock development in Alaba woreda, Southern Nations Nationalities and peoples region. A thesis submitted to the Faculty of Veterinary Medicine, Addis Ababa University, as apartial fulfillment of the requirements for the attainment of Degree, Doctor of Veterinary Medicine (DVM), Debreziet Ethiopia.

[24] Kassaye D; Molla W., 2012.Sero-prevalence of contagious bovine pleuropneumonia at export quarantine centers in and around Adama, Ethiopia. Trop Anim Health Prod; 45(1): 2759.

[25] Molla B, Delil F. 2015. Mapping of major diseases and devising prevention and control regimen to common diseases in cattle and shoats in Dassenech district of South Omo Zone, South-Western Ethiopia. Trop Anim Health Prod. 47(1):45-5.

[26] Olabode HOK, Mailafia S, Adah BMJ, Nafarnda WD, Ikpa LT, Jambalang AR, and Bello RH, 2013. Serological Evidence of Contagious Bovine Pleuro-Pneumonia antibodies in tradecattle (Bos Indicus) sold in Kwara state-Nigeria. Online International Journal of Microbiology Research.Volume 1, Issue 1, pp. 14-19.

[27] FAO-OIE-OAU/IBAR-IAEA Consultative Group on CBPP (Rome, 12-14 November 2003). Rome, Italy. 2004. Towards sustainable CBPP control programmes for Africa. 